\title{
Killing in the Name of Islam: Al-QAeda's Justification for September 11
}

\section{Quintan Wiktorowicz and John Kaltner}

Dr. Wiktorowicz is an assistant professor of international studies and Dr. Kaltner is an associate professor of religious studies, both at Rhodes College in Memphis, Tennessee. The al-Qaeda document that serves as the basis for this article is available in Arabic and English at www.mepc.org.

By means of this document we send a message to America and those behind it. We are coming, by the will of God almighty, no matter what America does. It will never be safe from the fury of Muslims. America is the one who began the war, and it will lose the battle by the permission of God almighty.

-Al-Qaeda statement, April 24, 2002

I $\mathrm{n}$ the wake of the September 11 attacks, President Bush moved quickly to dismiss al-Qaeda operatives as part of the lunatic fringe, religious usurpers bent on misrepresenting and "hijacking" Islam to serve terrorism. ${ }^{1}$ This characterization was echoed in the Muslim world, where an assortment of government officials, religious scholars and opposition figures fervidly denounced the killing of civilians as un-Islamic. ${ }^{2}$

Abdulaziz bin Abdullah al-Ashaykh, the mufti of Saudi Arabia, argued that "hijacking planes, terrorizing innocent people and shedding blood constitute a form of injustice that cannot be tolerated by Islam, which views them as gross crimes and sinful acts."3 Muhammed Sayyid alTantawi, the rector of al-Azhar University in Cairo, issued a similar condemnation: "Attacking innocent people is not courageous, it is stupid and will be punished on the day of judgment. . . . It's not courageous to attack innocent children, women and civilians. It is courageous to protect freedom, it is courageous to defend oneself and not to attack."4 Shaikh Yussuf alQaradawi, a prominent Islamic scholar and television personality from Qatar, emphasized that "Islam, the religion of tolerance, holds the human soul in high esteem, and considers the attack against innocent human beings a grave sin." 5

Even Islamic fundamentalist groups issued sharp denunciations. Forty-six leaders representing an assortment of Islamist movements and groups signed a letter opposed to the attacks:

The undersigned, leaders of Islamic movements, are horrified by the events of Tuesday 11 September 2001 in the United States, which resulted in massive killing, destruction and attack 
on innocent lives. We express our deepest sympathies and sorrow. We condemn, in the strongest terms, the incidents, which are against all human and Islamic norms. This is grounded in the Noble Laws of Islam, which forbid all forms of attacks on innocents. God Almighty says in the Holy Quran: "No bearer of burdens can bear the burden of another" (Surah al-Isra 17:15). ${ }^{6}$

Signatories included the general guide of the Muslim Brotherhood of Egypt, the amir of the Jamaat-i-Islami in Pakistan and Ahmad Yassin, the founder of Hamas.

To be sure, many of these condemnations were blunted by concomitant criticism of American foreign policy as the primary catalyst for al-Qaeda's war. Leaders throughout the Middle East, including traditional allies, cautioned the United States to reflect on the consequences of its "unbalanced" approach to the region (particularly vis-à-vis the Israeli-Palestinian conflict and Iraq), and public opinion in the Arab world indicated mounting resentment against perceived American hegemony and arrogance. Yet in the wake of September 11, U.S. allies and adversaries alike in the Muslim world joined President Bush in rejecting the radicalism of al-Qaeda.

Given this broad rejection, how could al-Qaeda defend killing thousands of innocent civilians in the name of Islam? Although pre-September 11 fatwas, interviews and statements by Bin Laden and al-Qaeda representatives clearly outlined the movement's belief that American civilians are legitimate targets, alQaeda had yet to articulate its religious rationale for attacks against civilian populations. In the first six months after September 11, al-Qaeda failed to issue a response to the maelstrom of criticism that de- nounced the attacks as un-Islamic. Then finally on April 24, 2002, al-Qaeda released an extended statement (approximately 3,700 words) outlining, for the first time, its religious justification for killing civilians in a total war against the United States, titled "A Statement from Qaidat al-Jihad Regarding the Mandates of the Heroes and the Legality of the Operations in New York and Washington." Unlike previous alQaeda statements, the justification was not published by Arabic or Western newspapers and has largely been ignored by experts. Yet it provides essential insights into the movement's religious rationale for September 11 that could help American policy makers in the war on terrorism.

The 2002 statement is best understood as part of an ongoing debate about the use of violence in Islam. Al-Qaeda is a component of a broader "fundamentalist" community and as a result is actively engaged in debates about religious authority, the legitimacy of war and rules of engagement in combat. In the 1990s, most disputes focused on whether it was permissible to rebel against incumbent regimes in the Muslim world. Toward the late 1990s, this focus shifted to address the United States as an emerging enemy and the legitimacy of particular tactics in warfare against unbelievers. The 2002 document is part of this latest debate and should therefore be understood as an argument that seeks not only to outline al-Qaeda's justification, but also address alternative, competing religious interpretations about acceptable violence in Islam.

\section{DEBATING VIOLENCE}

Al-Qaeda is a radical tendency within a broader Islamic movement known as the Salafi movement. The term Salafi is 
derived from the Arabic salaf, which means "to precede" and refers to the companions of the Prophet Muhammed. Because the salaf learned about Islam directly from the messenger of God, their example is an important illustration of piety and unadulterated religious practice. Salafis argue that centuries of syncretic cultural and popular religious rituals and interpretations distorted the purity of the message of God and that only by returning to the example of the prophet and his companions can Muslims achieve salvation. The label "Salafi" is thus used to connote "proper" religious adherence and moral legitimacy, implying that alternative understandings are corrupt deviations from the straight path of Islam. ${ }^{8}$

While Salafis all agree about the importance of the prophetic model and the paradigm of the companions, there are important interpretive differences that have engendered schisms within the movement, particularly over the proper method to create an Islamic society and protect the umma (Muslim community). Differences in interpretation tend to emphasize one of the following four basic methods for promoting Islam:

1) Propagation (dawa). Salafis who focus on this method emphasize personal piety, cleansing the corpus of hadiths (reported sayings and traditions of the Prophet Muhammed), and spreading proper Islam. For this group, the priority is for individuals to practice a pure understanding of Islam. This entails not only propagation and individual piety, but a program to eliminate any weak or false hadiths so that Muslims ensure they are truly following the prophetic model.

2) Advice. A large number of influential Salafis and their followers believe that it is the responsibility of the ulama (religious scholars) to advise leaders about Islamic legislation and regulations. In general, however, they believe this advice should be given in private.

3) Non-violent action. Some Salafis believe that it is the duty of Muslims (particularly the ulama) to openly speak out against un-Islamic actions, decisions and public policy. This can include the use of the khutba (Friday sermon), open letters, public speeches, demonstrations and rallies.

4) Violent action. A small, radical fringe in the Salafi community argues that it is an Islamic duty to use violence to remove leaders who do not properly follow or enforce Islam. Known as jihadis, these Salafis do not reject the other methods, but they do emphasize the necessity of violence. Al-Qaeda is part of this group.

These differences have produced debates about the proper methodology for promoting Islam, leading to often vitriolic conflicts. Because Salafis believe that there is only one accurate understanding of Islam - the model of the prophet and his companions - this creates a tendency to dismiss any differences of interpretation as deviations. It is quite common, for example, for one Salafi group to call scholars and followers from other clusters to "return to the straight path." This has even generated disagreements over who can be considered a Salafi. In particular, nonviolent Salafis, who make up the vast majority of the movement, often vehemently reject use of the Salafi label to describe the violent or jihadi elements. ${ }^{9}$ The latter, however, identify themselves as Salafis and dismiss the other groups as misguided, ignorant (unknowledgeable 
about Islam) or corrupt.

The debate within the Salafi community over the use of violence has divided the movement more than any other issue. During the 1990s, as al-Qaeda developed, the initial debate between violent and nonviolent Salafis was over takfir - declaring a Muslim an apostate. Declaring a Muslim an unbeliever is a serious endeavor, since it could mean a death sentence. The central axis of divergence was over whether one could judge a ruler in the Muslim world an apostate according to his actions. Nonviolent groups argued that one can never know with certainty what is in an individual's heart and that so long as a ruler has a "mustard seed of iman (belief)," he is considered a Muslim, especially if he allows Muslims to pray and generally practice their religion. The jihadi Salafis, on the other hand, argued that the oneness of God (tawhid) demands that Muslims follow Islam in both belief and action. In other words, an un-Islamic belief is just as revealing as an un-Islamic action. As a result, the jihadis charged the Saudis and other regimes in the Muslim world with unIslamic behavior and thus apostasy, and called for a jihad to remove them.

In the late 1990s, although this debate continued, it became less relevant to Islamist struggles on the ground as jihadis faced defeat and marginalization throughout the Middle East. This was particularly the case in the largest Islamist insurgencies in Egypt and Algeria. ${ }^{10}$ In Egypt, leaders from both the Islamic Group and Islamic Jihad declared cease-fires, and the violence came to a dramatic end. Elements from within the Islamic Group went so far as to issue a public apology for the violence and published a four-volume justification for the decision. In a move that epitomized the recasting of the jihadis, a number of Islamists from both groups attempted to establish political parties (the Sharia and Islah parties), though the regime rejected the requests for permits. Violent jihadi dissidents found themselves marginalized; many left for Pakistan and Afghanistan to work directly with al-Qaeda.

In Algeria, a similar process occurred. The regime's decision to cancel elections in 1992 , as Islamists were poised to control parliament, sparked an insurgency that has claimed more than 150,000 lives. Early in the conflict, the jihadi Salafis united under the banner of the Armed Islamic Group (GIA) and attacked government officials and soldiers. In 1996, however, the GIA launched a series of civilian massacres that undermined the unity of the Islamist opposition; and groups such as the Islamic Salvation Army issued a unilateral ceasefire. The regime responded by using an amnesty program to reintegrate former Islamist fighters into society. Although a number of radical groups continue to operate, the violence has dropped substantially since the late 1990s. As a result, many Algerian jihadi Salafis placed their networks, resources and personnel at the 
Middle East Policy, Vol. X, No. 2, Summer 2003

service of al-Qaeda. ${ }^{11}$

For non-violent Salafis, these defeats made it clear that the jihadi vision to unseat incumbent Arab regimes was at an end (at least in the short term), and so the issue of takfir became less prominent in debates over violence. Instead, the focus shifted to al-Qaeda's war against the United States and its allies. In general, most Salafis agree that the United States is waging a war of aggression against Muslims through its actions in Afghanistan, Pakistan, Iraq and elsewhere. Differences emerge, however, over the proper response and course of action. Jihadis once again call for violence, while the non-violent Salafis promote other means, including public announcements of opposition to a U.S. presence in the Middle East, prayer, and advice to Arab and Muslim leaders.

This is the context in which one should understand al-Qaeda's 2002 justification for September 11 and the purposeful targeting of civilians. The document is part of a discursive contest over the proper methodology for fulfilling religious obligations. As a result, it reflects a carefully constructed case to undermine the legitimacy of non-violent solutions. In this respect, it makes three important arguments. First, proponents of a non-violent response to the United States are corrupt, ignorant and/or hypocritical, and therefore are not credible religious mediators. This is contrasted with the scientific, independent and religiously authentic interpretation of the jihadi Salafis. Second, the United States is waging a war against Islam. Therefore, violence is a defensive jihad that is incumbent upon all Muslims. And third, there is no unconditional prohibition against killing civilians in Islam. In fact, civilians can be purposely targeted under certain conditions, and these conditions are met in the current climate.

\section{PERSUASION AND CREDIBILITY}

For Muslims, scholars of Islam play a critical role as intermediaries between the sacred texts and everyday religious rituals and practices. They are seen as the inheritors of the prophetic message, intellectually equipped to interpret the immutable sources of Islam in light of the changing conditions of the temporal world. For Islamists, the scholars are central nodes in networks of religious meaning, responsible for providing guidance and mentoring students so that they might follow the straight path of Islam to Paradise in the hereafter. They provide religious interpretations and offer lessons, books and lectures for those seeking enlightenment. For Salafis, in particular, scholars are essential, since they are purveyors of knowledge capable of illuminating an unadulterated understanding of Islam based upon the example of the prophet and his companions.

Not all scholars are equal, however. There are differences in training, intellectual capacity, communicative skills and charisma, all of which affect the reputation and influence of individual scholars. Those with strong reputations develop extensive followings and can use fatwas and other vehicles to exert substantial influence. The term "scholar" (alim) itself does not reflect objective criteria of learning; it is subjectively derived recognition dependent upon the reputation of the individual. Whether an individual is recognized as a scholar in good standing determines the likelihood that his interpretation will be accepted.

The debate over the conditions for permissible violence is therefore more than 
merely a conflict over ideas; it is a struggle over sacred authority - the right to interpret Islam on behalf of the Muslim community. ${ }^{12}$ As studies of persuasion and framing have noted, the impact of an argument is determined not only by its resonance with the experiences and worldview of the target audience, but by the credibility of the articulator as well. ${ }^{13}$ Influence is contingent upon the trustworthiness and integrity of the scholar. A lack of credibility can undermine the effect of a religious interpretation or argument by leading an audience to question the intentions of the source and thus whether the message represents an honest assessment of Islam and the will of God.

The jihadi scholars who nurture alQaeda and provide religious cover for acts of violence suffer from a "reputation deficit." Many are self-taught, new Islamist intellectuals with little formal religious training. Others have spent their lives studying Islam, but a dearth of resources, sponsors and fora for communication limits their capacity to develop a reputation. There are a few classically trained jihadi scholars with global notoriety, such as Omar Abdul Rahman (the Azharite shaikh and former mufti of several radical Egyptian groups, now in jail in New York), but these are the exceptions. This is in contrast to the training of the non-violent Salafi scholars, many who hold PhDs from established Islamic universities in Saudi Arabia and are considered part of the ulama in the kingdom. Non-violent Salafis thus find ample opportunity to dismiss the jihadis as unknowledgeable or ignorant, a pejorative insult among Salafis, who pride themselves as students of learning.

The case of Umar Abu Qatada, one of the key religious scholars of the al-Qaeda network, highlights this reputation deficit. Abu Qatada began his religious training with Mohammed Nasir al-Din al-Bani (d. 1999), a renowned Salafi reformist who came to Jordan after fleeing Syria in the late 1970s. Abu Qatada was part of a small group of teenage students that included eventual luminaries of the nonviolent Salafi community, such as Salim alHilali and Ali Hasan al-Halabi. He left alBani's study circle over the issue of violence and continued his studies elsewhere, eventually fleeing security services in Jordan and relocating to London. Abu Qatada developed an impressive reputation among small jihadi circles and became an important reference point for the radical jihadis in Algeria (both the GIA and the Salafi Group for Call and Combat, or GSPC). His centrality as a jihadi scholar is exemplified by his participation on the fatwa committee of al-Qaeda. ${ }^{14}$ After the 9/11 attacks, Abu Qattada, who became known as al-Qaeda's European paymaster, went underground; but he was caught in the UK and imprisoned in late 2002.

Despite this considerable history, reformists quickly dismiss Abu Qatada as unknowledgeable. For example, when asked about Abu Qatada in an interview, Salim al-Hilali quickly denounced him as ignorant and claimed, "He is not a scholar." 15 Such assaults on the credibility of the jihadi scholars are common among the non-violent Salafis.

As a result, much of the 2002 document can be seen as an attempt to establish the credentials of the jihadis while demeaning the credibility of the non-violent reformists. Since formal pedigree favors the reformists, jihadis stress the issue of scholarly independence and integrity. The thrust of this line of argument is that the 
reformist scholars are "the rulers' shaikhs" - mouthpieces for Arab regimes, which, in turn, are puppets of the United States. This connotes an inextricable connection between reformist legal rulings about violence and the desire of authorities to protect American interests, thus implying that non-violent Islamic interpretations are corrupted by politics and therefore unreliable and deceitful. This is clearly the argument at the onset of the document:

We pass on this initial report, without details or exposition, regarding the evidence of the legality of this kind of operation. Let it be a quick message to those who dress their political opinions in the garb of a legal ruling. Let it also be a call to those who oppose and condemn the operations to obey Allah, repent and return to the legal evidence. Cowardice in defending the warriors (mujahidin) is no better than being silent. Allah is our guide and the guide of all Muslims.

Elsewhere, the connection between opposition to the violence of al-Qaeda and the dubiousness of reformist legal rulings is again emphasized:

These great events which changed the face of history on such a grand scale occurred in the umma, and it will be a great regret to anyone who blames those who brought about the operation of September. Those ignorant ones do not speak with legal evidence or reasonable logic. Rather, they speak in their masters' languages [i.e., Saudi Arabia] and in the concepts of the enemy of the umma [i.e., the USA].

The jihadis go even further and charge the reformists with apostasy because of their support for the American war on terrorism, an extreme condemnation that, if true, would eliminate the reformists' right to issue legal rulings.
Despite the clarity of the matter and the obvious nature of the evidence, however, it is regrettable that many of the motives were destroyed in the comforting of America, the expres- sions of sorrow for her, and the legal rulings to assist her and to donate blood for her innocent (!!) victims. Legally incriminating the one who carried out the operations and expelling him from Islam is also regrettable, as is giving the Crusaders the green light to exact revenge on Muslims. This teaches all those who issue opinions that America may pursue the Afghans and Shaikh Usama Bin Laden, may Allah protect him. We warn them about apostasy because of their assistance to the Crusaders by word or by their legal rulings to Arab governments that cooperation against terrorism [by this they mean cooperation against the mujahidin] is lawful. This is defiant apostasy!

The document argues that the corruption of these religious scholars is clearly demonstrated by the hypocrisy of their rulings: the reformists condone the use of martyrdom (suicide) operations in Palestine against Israelis (including civilians) yet denounce similar operations against Americans, such as the September 11 attacks. ${ }^{16}$ The jihadis categorize both the Israelis and Americans as "people of war": Israel occupies and oppresses Muslims in Palestine; the United States oppresses and attacks Muslims in Afghanistan, Iraq and elsewhere. More important, Israel is 
portrayed as an extension of an American policy to attack the Muslim world, thus representing the conflict in Palestine as only one of many strategic components designed to support U.S. aggression. As a result, they argue, one can use the same tactics and strategies against both. Those who think otherwise are influenced by a political agenda that ignores the sources of Islam and the evidence legitimating September 11:

[Y]ou will truly be surprised by those who rule that the martyrdom operations in Palestine in which civilians fall victim are among the highest forms of jihad, and then rule that the martyrdom operations in America are wrong because of civilian deaths. This inconsistency is very strange! How can one permit the killing of the branch and not permit the killing of the supporting trunk? All who permit martyrdom operations against the Jews in Palestine must allow them in America. If not, the inconsistency leads to nothing but a type of game playing with the legal ruling.

The hypocrisy and treachery of the non-violent Salafi scholars is contrasted with the independence and purity of the jihadis' intentions. Whereas the reformists are seen as inspired by political ambition and the interests of the United States and its Arab allies, the jihadis are characterized as influenced only by a desire to implement divine will:

[T]he only motive these young men had was to defend the religion of Allah, their dignity, and their honor. It was not done as a service to humanity or as an attempt to side with Eastern ideologies opposed to the West. Rather, it was a service to Islam in defense of its people, a pure act of their will, done submissively, not grudgingly. ${ }^{17}$

The 2002 document notes the purity of the mission with pride. And, in an interesting shift from earlier denials, al-Qaeda not only accepts its responsibility for September 11, but claims "that hiding all trace of the agents of the operation was not something we considered. Rather, some of the heroes were intent on leaving Islamic fingerprints on the operation."

The purity of the jihadis is contrasted with the corruption of their detractors in an effort to impugn the reputation, credibility and persuasive effect of alternative religious interpretations. As part of the debate over the use of violence in Islam, the document reflects the Salafi emphasis on the centrality of reputable scholars capable of interpreting Islam and providing guidance for others. Character assassination and charges of deception and ignorance are devices intended to weaken opposing arguments.

\section{JUST WAR AND JIHAD}

In Islam, there are two types of external jihad: offensive and defensive. ${ }^{18}$ In Islamic jurisprudence, the offensive jihad functions to promote the spread of Islam, enlightenment and civility to the dar alharb (domain of war). In most contemporary interpretations, the offensive jihad can only be waged under the leadership of the caliph (successor to the prophet). It is tempered by truces and various reciprocal agreements between the Islamic state and non-Muslim governments, such as guaranteed freedom of worship for Muslim minorities. Today, very few Islamists focus on this form of jihad. 
The defensive jihad (jihad al-dafaa), however, is a widely accepted concept that is analogous to international norms of selfdefense and Judeo-Christian just-war theory. ${ }^{19}$ According to most Islamic scholars, when an outside force invades Muslim territory, it is incumbent upon all Muslims to wage jihad to protect the faith and the faithful. Mutual protection is seen as a religious obligation intended to ensure the survival of the global Muslim community. At the root of defensive jihad is a theological emphasis

on justness, as embodied in chapter 6 , verse 151 of the Quran: "Do not slay the soul sanctified by God except for just cause." Defending the faith-based community against external aggression is considered a just cause par excellence.

In the contemporary period, this widely accepted notion of the defensive jihad was first put to the test in Afghanistan in the 1980s. After the Soviets invaded Afghanistan in 1979 to prop up a failing communist government, Islamic scholars throughout the Muslim world called for jihad. Thousands of Muslim fighters flocked to Afghanistan to fulfill their religious duty, supported by Islamic charities, wealthy individuals and governments in Muslim countries such as Saudi Arabia, Kuwait and Pakistan. State leaders and radical Islamists alike concurred that the jihad was an Islamic duty that could include fighting, financial support, humanitarian work or verbal assistance, depending on an individual's capacities and resources. This broad agreement was extended to justify support for jihad in other conflicts as well, including Bosnia and Chechnya.

In a disturbing confluence of opinion regarding jihad, the focus on the just nature of defensive war united both mainstream Islamic scholars and al-Qaeda in opposition to the U.S. invasion of Iraq in March 2003. In a tape aired by al-Jazeera television on February 11, 2003, as the U.S.-led coalition built its forces on the borders of Iraq, Bin Laden continued his call for jihad against the U.S. "crusaders" and their pending invasion. ${ }^{20}$ Only a month later, before the invasion took place, Islamic scholars at al-Azhar University (Cairo), the oldest Islamic university in the world, echoed Bin Laden's sentiments and emphasized the need for a defensive jihad: "According to Islamic law, if the enemy steps on Muslims' land, jihad becomes a duty on every male and female Muslim."21 Although the al-Azhar scholars may have used the term "jihad" to mean non-violent struggle, the justification shared al-Qaeda's theological understanding about the defensive nature of any such jihad.

Consistent with this understanding, the 2002 document frames September 11 and other al-Qaeda operations as defensive measures to protect the Muslim community from outside aggression. The argument repeats the framing in earlier al-Qaeda documents and includes a litany of U.S. aggressions and crimes against Islam: support for Israel against the Palestinians; support for Serbian genocide against 
Bosnian Muslims; support for India against the Kashmiris; the U.S. invasion of Afghanistan; actions in East Timor; support for the Philippine aggression against Muslims in the south. The document frames these examples as indicative of a nefarious "Zionist-Crusader" plot to annihilate Muslims. Under this assault, alQaeda argues that violence is the only solution: "The only way to liberation from this humiliation is the sword, which is the only language the enemy understands that will deter it." September 11 is thus portrayed as a defensive response necessary to thwart U.S. aggression against the Muslim world.

The document also addresses a very particular criticism of al-Qaeda's war against the United States. A number of Salafis and Islamists have argued that, since Muslim governments made treaties and agreements with the United States and its Western allies, it is illegal in Islam to wage jihad against them. This is based, in part, upon a story narrated by Abdullah bin Amr in which the prophet said, "Whoever kills a muahid [a treaty partner] shall not smell the fragrance of Paradise though its fragrance can be smelt at a distance of forty years (of traveling)." ${ }^{\prime 22}$ However, in many interpretations of Islamic law, treaties are revisited every ten years, and so revisions can be made depending upon changing conditions, needs or strategies. If the non-Muslim partner violates the treaty conditions first, the agreement is voided.

Responding to this line of argument, alQaeda dismisses the premise that the Muslims ever had viable treaties with the United States. To some extent, this is based upon the jihadi belief that governments in Muslim countries are controlled by apostate regimes and therefore cannot legitimately make treaties on behalf of Muslims. Such contracts are therefore null and void.

In addition to this outright rejection, alQaeda evaluates the argument on its own basis and poses a counterargument. Suppose a treaty really did exist? Is it still valid? The document argues that the innumerable acts of U.S. aggression constitute massive breaches of any hypothetical agreement. These violations render the "treaty" meaningless:
Truly, America is not, nor has it ever been, a land of treaty or alliance. If we were to line up with the other side and say that it is a land of peace, we would say that it has turned into a land of war. That occurred with its violation of the treaty and its help to the Jews for more than fifty years in occupying Palestine, banishing its people and killing them. It is a land of war that violated its treaty when it attacked and blockaded Iraq, attacked and block- aded Sudan, attacked and blockaded Afghanistan. It has oppressed Muslims in every place for decades and has openly supported their enemies against them.

For al-Qaeda, there is no treaty, and the U.S. "atrocities" against Muslims provide the rationale for a just and defensive jihad. The argument is rooted in widely accepted Islamic principles about justice and the legitimacy of a defensive struggle and therefore appeals to mainstream understandings about warfare.

\section{RULES OF ENGAGEMENT AND CIVILIAN TARGETING}

Fighting and killing in the name of Islam are conditional, and there are important rules of engagement that dictate and 
limit targets and tactics. The Prophet Muhammed expended great energies elaborating what was and was not permissible during wartime, demonstrating the importance of restraint and caution on the battlefield. The prohibitions against killing innocent civilians, in particular, are numerous, and non-violent Salafis and others quote a number of hadiths to support their opposition to the September 11 attacks, including,

Set out for jihad in the name of Allah and for the sake of Allah. Do not lay hands on the old verging on death, on women, children and babes. Do not steal anything from the booty and collect together all that falls to your lot in the battlefield and do good, for Allah loves the virtuous and the pious.

Many scholars also quote Abu Bakr, the first caliph or successor to the Prophet Muhammed. He gave the following instructions to a Muslim army setting out to battle against the Byzantine Empire in Syria:

\begin{abstract}
Stop, O people, that I may give you ten rules for your guidance in the battlefield. Do not commit treachery or deviate from the right path. You must not mutilate dead bodies. Neither kill a child, nor a woman, nor an aged man. Bring no harm to the trees, nor burn them with fire, especially those which are fruitful. Slay not any of the enemy's flock, save for your food. You are likely to pass by people who have devoted their lives to monastic services; leave them alone.
\end{abstract}

In his response to the September 11 attacks, the mufti of Saudi Arabia focused on the need to be fair and just, quoting an assortment of Quranic verses prohibiting oppression, such as "O My servants, indeed I have forbidden oppression upon Myself and I have also made it forbidden amongst yourselves, hence to not oppress each other," and "O you who believe. Be of those who stand up to Allah, as witnesses of justice. And let not the hatred of a people make you swerve away from justice toward them. Verily, be just, and that is closer to piety." ${ }^{23}$ Qaradawi builds on such verses as well, highlighting Quran 5, 32: "Whosoever kills a human being for other than manslaughter or corruption in the earth, it shall be as if he has killed all mankind, and whosoever saves the life of one, it shall be as if he had saved the life of all mankind." 24

Al-Qaeda, however, disputes the broad prohibition against killing civilians on two grounds. First, it takes issue with the notion that those killed in the September 11 attacks were "innocents" covered by the prophet's prohibitions. Second, al-Qaeda argues that the prohibition is not an absolute one and that there are conditions under which killing civilians becomes permissible. The movement thus takes on both the theological argument proffered against the September 11 attacks and reformist framings of the victims as innocent. The result is a broad set of conditions that provide religious justification for killing civilians in almost every possible circumstance. Only one condition need be met to legitimize an attack against civilians.

\section{Condition One: The Norm of Reciprocity}

The sources of Islam provide clear prohibitions against killing civilians, but alQaeda argues for reciprocal attacks. This is justified with reference to Quran 2, 194: "And one who attacks you, attack him in 
like manner as he attacked you." Thus, if the enemy uses tactics that are prohibited in Islam, these tactics become legal for the Muslims. Since the document makes the case that America has purposely targeted Muslim civilians, it presses readers to accept the logical conclusion that civilian targeting, as in September 11, is now legal. This point is emphasized with particular reference to the Palestinian struggle:

There currently exists an extermination effort against the Islamic peoples that has America's blessing, not just by virtue of its effective cooperation, but by America's activity. The best witness to this is what is happening with the full knowledge of the world in the Palestinian cities of Jenin, Nablus, Ramallah and elsewhere. Every day, all can follow the atrocious slaughter going on there with American support that is aimed at children, women and the elderly. Are Muslims not permitted to respond in the same way and kill those among the Americans who are like the Muslims they are killing? Certainly! By Allah, it is truly a right for Muslims.

For al-Qaeda, the evidence points to a clear conclusion:

It is allowed for Muslims to kill protected ones among unbelievers as an act of reciprocity. If the unbelievers have targeted Muslim women, children and elderly, it is permissible for Muslims to respond in kind and kill those similar to those whom the unbelievers killed.

\section{Condition Two: Inability to Distinguish Civilians from Combatants}

When attacking an enemy "stronghold" it may be difficult to distinguish combatants from non-combatants, particularly if enemy fighters hide among the general population. The Arabic term the document uses for "stronghold" (hisn) has an interesting semantic range in light of the targets of September 11. It refers to a place that is immune to attack either because it is well fortified or because great height makes it impregnable. ${ }^{25}$ The connection with the targets is obvious - what American sites have been more clearly associated with fortification and height than the Pentagon and the World Trade Center? Al-Qaeda argues that so long as the stronghold is a legitimate target and enemy fighters are present, Muslims can attack, even if this means civilian casualties: "It is allowed for Muslims to kill protected ones among the unbelievers in the event of an attack against them in which it is not possible to differentiate the protected ones from the combatants or from the strongholds." So even if one grants the argument that there were innocent civilians in the buildings, which al-Qaeda does not accept, the buildings can still be attacked.

The document cites as evidence a story in which Muslims asked about the offspring and women of unbelievers who stayed behind with the enemy fighters and were killed. The prophet was said to reply, "They are from among them." In this story, the women and children of the enemy preferred to remain with their men rather than flee to safety. Once they made that decision, they ceased to be innocents because they had aligned themselves with the combatants and were now legitimate targets for the Muslim forces. The alQaeda document suggests that those in the World Trade Center and the Pentagon should be viewed in the same way. The distinction between combatants and 
civilians is thereby erased since some of the latter chose to remain in "enemy territory."

\section{Condition Three: Assistance of} Civilians in "Deed, Word or Mind"

In Islamic law, the legitimacy of a target in the context of a war is typically determined by the capacity of that target or individual to fight against the Muslims. This includes enemy soldiers and leaders, as well as advisers to the military and the enemy leadership, including civilian advisers. The vast majority of civilians, however, are excluded from target lists because they are not actively engaged in battle, especially women, children and the elderly, whose capacity to fight is considered minimal in most cases. $^{26}$

Al-Qaeda, however, broadens the definition of active participation to include roles that indirectly assist the enemy:

It is allowed for Muslims to kill protected ones among unbelievers on the condition that the protected ones have assisted in combat, whether in deed, word, mind or any other form of assistance, according to the prophetic command.

This is based upon a story about Duraid Ibn al-Simma, a well-known Arab poet who strongly opposed Muhammad and the message of Islam. According to tradition, he was brought to the battlefield to advise the Hawazin troops about battle procedures in a conflict against the Muslims. As a very old man, he posed no physical threat to the Muslim forces, but the intelligence he provided to the enemy made him a target and led to his death in battle.

But al-Qaeda's use of this story creates an expanded understanding of combat assistance that includes not only direct support through physical participation or advice to war planners, but less direct support as well. From this perspective, the press and journalists are legitimate targets because they are American propaganda tools in the war against al-Qaeda. Academics and intellectuals working on Islam and/or terrorism can be killed because their studies and publications help inform government officials and provide knowledge that can be used against the Muslims. Employees working in businesses that supply the government and/or military can be targeted because they provide equipment and services that support the war or the leaders waging the campaign.

The breadth of this category is underscored by al-Qaeda's understanding of American democracy. It reasons that since a democratically elected government reflects the will of the people, a war against Islam of this magnitude must have popular support. Using the term "public opinion" (al-ray alamm) to represent the will of the people in a democracy, al-Qaeda argues that,

It is stupidity for a Muslim to think that the Crusader-Zionist public opinion which backs its government was waiting for some action from 
Muslims in order to support the Crusader war against Islam and thereby enkindle a spirit of hostility against Islam and Muslims. The Crusader-Zionist public opinion has expended all it has in order to stand behind the nations of the cross, executing their war against Islam and Muslims from the beginning of the colonization of Islamic countries until the present day. If the successive Crusader-Zionist governments had not received support from their people, their war against Islam and Muslims would not have taken such an obvious and conspicuous form. It is something that would not attain legitimacy except by the voices of the people.

This reflects the logic of an earlier fatwa issued by Hammoud al-Uqla alShuaybi just after September 11, which was adopted by the jihadi Salafis. In the fatwa, al-Shuaybi argues,

[W]e should know that whatever decision the non-Muslim state, America, takes - especially critical decisions which involve war - it is taken based on opinion polls and/or voting within the House of Representatives and Senate, which represent directly, the exact opinion of the people they represent - the people of America - through their representatives in the Parliament [Congress]. Based on this, any American who voted for war is like a fighter, or at least a supporter. ${ }^{27}$

Given this perspective, al-Qaeda scoffs at the notion that those killed in the September 11 attacks, including those in the World Trade Centers were "innocent civilians." These individuals could be targeted because they assisted the government in its war against Muslims by "deed, word or mind." The economic significance of the towers as sources of revenue for the government (through taxes or business, for example) further damned its occupants.

This condition is so expansive as to include virtually any individual in the United States (or allied countries).

\section{Condition Four: The Necessity of War}

The document argues that it is permissible to "kill protected ones among the unbelievers in the event of a need to burn the strongholds or fields of the enemy so as to weaken its strength in order to conquer the stronghold or topple the state." Throughout, al-Qaeda defines the World Trade Centers as enemy "strongholds," in effect directly linking the centers to the government and thus to the "war" against Muslims. In such an interpretation, the use of flying suicide bombs is equivalent to "burning" the stronghold.

\section{Condition Five: Heavy Weaponry}

Al-Qaeda uses a story about the prophet in which he was asked whether the Muslim fighters could use the catapult against the village of Taif, even though the enemy fighters were mixed with a civilian population. The Arabic term for catapult (manjaniq) refers to any stone throwing siege engine. In the early Islamic period and later, such devices proved quite effective against targets that were well fortified and difficult to overcome, but they were inaccurate and imprecise. Taif, located southeast of Mecca, was taken by Muslim forces in $630 \mathrm{CE}$. They resorted to the use of catapults in their assault because the city was surrounded by a high brick wall. A1-Qaeda likens the catapult as a 
heavy weapon to the planes used in the September 11 attacks. This is also the religious evidence used by jihadis to rationalize the acquisition and possible use of weapons of mass destruction.

\section{Condition Six: Human Shields}

Al-Qaeda argues that it is permissible to kill women, children and other protected groups if the enemy uses them as human shields (turs). Although the religious evidence for this is not outlined in the document, it seems to derive from a fatwa by the medieval Islamic jurist Ibn Taymiyya that is widely cited by jihadis:

The Islamic scholars have unanimously agreed that when the Kafir [unbeliever] takes Muslims as human shields, and the Muslims fear defeat if they do not attack, then it becomes permissible to fire, but we aim at the Kafir. Some scholars have said that it is permissible to fire even if ceasing fire will not form any kind of danger to Muslims. ${ }^{28}$

This understanding is thus rooted in the consensus of the scholars rather than explicit textual evidence.

\section{Condition Seven: Violation of a Treaty}

The final condition is when the enemy violates its treaty with the Muslims. "It is allowed for Muslims to kill protected ones among unbelievers if the people of a treaty violate their treaty and the leader must kill them in order to teach them a lesson. This is just as the Prophet did among the Bani Qurayza." According to Islamic tradition, Muhammad made a treaty with the Qurayza tribe soon after the hijra, or migration to Medina in $622 \mathrm{CE}$. It is reported that he was later persuaded to break that alliance and tear up the treaty. The Qurayza did not engage in hostile activity against Muslims but probably negotiated with the enemy while Medina was under attack. Upon learning of their betrayal, Muhammad besieged them for 25 days. When they unconditionally surrendered, their men were killed and their women and children were sold into slavery.

The sheer breadth of these conditions leaves ample theological justification for killing civilians in almost any imaginable situation. The notion that civilians become legitimate targets because of "deed, word, mind or any other form of assistance" (condition three) is so broad that it encompasses virtually every American. This is particularly the case since the document emphasizes the connection between supportive public opinion in a democracy and the ability of the government to wage an extended war against Muslims. And since only one condition need be met to provide a religious rationale for attack, alQaeda justifies terrorism under an almost inexhaustible array of possible scenarios and conditions.

\section{CONCLUSION: ECHOES OF ALGERIA}

These justifications echo the rationale used by jihadi Salafis during the civil war in Algeria, which could foreshadow the future direction of al-Qaeda operations. During the conflict between the government and Islamist rebels, jihadi groups massacred civilians, assassinated public personalities (including Berber singers, feminist leaders and academics), and targeted members of the press. Between 1996 and 1998, civilians were killed en masse in a directed and purposeful strategy of total war that 
eventually claimed more than 150,000 lives (mostly civilians). The rationale used to justify these killings represents a chilling precursor to the 2002 al-Qaeda document.

As in the al-Qaeda justification, the jihadis in Algeria broadened the understanding of combat to include any individual or group seen as complicit in the regime's counterinsurgency efforts against the Islamists. In an interview with al-Djamaa, which claimed to represent the "official voice of the GIA in the West," GIA chief Abu al-Moudhir argued that civilians who fought against the jihad by "force, talk or with the pen" were legitimate targets, ${ }^{29}$ reflecting a doctrine of total war. As a GIA communiqué put it, "There is no neutrality in the war we are waging. With the exception of those who are with us, all others are apostates and deserve to die." ${ }^{30}$

This Manichaean worldview condemned broad swathes of the civilian population to death. Reporters and the press were attacked as extensions of the regime used to "cover its crimes and rationalize its aggression." 31 The jihadis supported killing those "who do not pray, who drink alcohol and take drugs, homosexuals, and immodest or debauched women." ${ }^{32}$ Seven Trappist monks were beheaded for "mixing with [the Algerian people], living with them, and blocking the way of Allah by calling people to Christianity, and these are the worst ways of fighting the religion of Allah and Muslims." ${ }^{33}$ Even children attending government-controlled schools were not immune to violence. ${ }^{34}$ The scope of the violence was startling, and no quarter of society was immune from attack.

Given the stark parallels between the justifications for killing civilians in Algeria and the 2002 al-Qaeda document, the Algerian conflict may portend the future direction of al-Qaeda operations. Algerian jihadis attacked civilians with machetes, burned people alive, and slit throats in a brutal violence rationalized through broad categorization of legitimate civilian targets. The murder of reporter Daniel Pearl, whose throat was slit by al-Qaeda operatives in Pakistan, mirrors the brutality of the Algerian campaign. Al-Qaeda has thus far relied mostly on bombs and planes, but it is clear from the 2002 document that the echoes of Algeria could become louder as the jihadis continue to expand their war against U.S. civilians.

\footnotetext{
${ }^{1}$ Address to a Joint Session of Congress and the American People, September 20, 2001. Available at http:// www.whitehouse.gov/news/releases/2001/09/20010920-8.html.

${ }^{2}$ See www.unc.edu/ kurzman/terror.htm for a listing with sources. In the following quotes, the original sources are cited.

${ }^{3} \mathrm{http}: / /$ saudiembassy.net/press_release/01-spa/09-15-Islam.htm.

${ }^{4}$ Agence France Presse, September 14, 2001.

${ }^{5} \mathrm{http} / / / w w w . i s l a m o n l i n e . n e t / E n g l i s h / N e w s / 2001-09 / 13 /$ article25.shtml.

${ }^{6}$ MSANews, September 14, 2001, http://msanews.mynet.net/MSANEWS/200109/20010917.15.html; Arabic original in al-Quds al-Arabi (London), September 14, 2001, p. 2, http://www.alquds.co.uk/Alquds/ 2001/09Sep/14\%20Sep\%20Fri/Quds02.pdf.

${ }^{7}$ Although al-Qaeda's main website was shut down after September 11, it was subsequently hosted at various alternative sites, including one run by The Center for Islamic Studies and Research (markaz al-dirasat walbuhuth al-islamiyyah), which posted the al-Qaeda statement. We would like to thank Paul Eedle for bringing the document to our attention.

${ }^{8}$ See Quintan Wiktorowicz, "The New Global Threat: Transnational Salafis and Jihad," Middle East Policy, Vol. 8, No. 4, December 2001, pp. 18-38, and The Management of Islamic Activism: Salafis, the Muslim
} 
Middle East Policy, Vol. X, No. 2, Summer 2003

Brotherhood, and State Power in Jordan (Albany: State University of New York Press, 2001).

${ }^{9}$ Wiktorowicz's interviews with Salafis in Jordan from 1996-1997 and a phone conversation with the president of the Quran and Sunna Society of North America (a U.S.-based Salafi organization), February 18, 2002. After Michael Doran published "Somebody Else's Civil War" in Foreign Affairs, Vol. 81, No. 1, January/February 2002, pp. 22-42, he received an onslaught of complaints from non-violent Salafis for his characterization of al-Qaeda as part of the Salafi movement (Wiktorowicz's conversation with Doran, December 2002).

${ }^{10}$ See, for example, Fawaz Gerges, "The Decline of Revolutionary Islam in Algeria and Egypt," Survival, Vol. 41, No. 1, Spring 1999, pp. 113-125.

${ }^{11}$ See Quintan Wiktorowicz, "The GIA and GSPC in Algeria," In the Service of al-Qaeda: Radical Islamic Movements, ed. Magnus Ranstorp (New York: Hurst Publishers and New York University Press, forthcoming).

${ }^{12}$ Dale F. Eickelman and James Piscatori, Muslim Politics (Princeton, NJ: Princeton University Press, 1996).

${ }^{13}$ See, for example, Robert D. Benford and David A. Snow, "Framing Processes and Social Movements: An Overview and Assessment," Annual Reviews in Sociology, No. 26, 2000, pp. 611-639.

${ }^{14}$ United States District Court vs. Usama Bin Laden et al., 2001.

${ }^{15}$ Wiktorowicz's interview with Salim al-Hilali, Amman, Jordan, April 2, 1997.

${ }^{16}$ Many leading Islamic figures who condemned the attacks in New York and Washington have lent their support to Hamas attacks in the Palestinian territories, including well-known scholars such as Qaradawi. ${ }^{17}$ This characterization was repeated by Bin Laden in a tape aired on al-Jazeera television prior to the U.S. invasion of Iraq in 2003. Perhaps addressing charges that al-Qaeda is linked to Saddam Hussein, he emphasizes that the mujahidin must fight "for the sake of the one God" and that "fighting in support of the nonIslamic banners [ethnicity, nation, etc.] is forbidden. Muslims' doctrine and banner should be clear in fighting for the sake of God. He who fights to raise the word of God will fight for God's sake." An English translation of the tape is available at $\mathrm{http}: / /$ news.bbc.co.uk $/ 2 / \mathrm{hi} / 2$ middle east $/ 2751019 . \mathrm{stm}$.

${ }^{18}$ In addition to the external jihad, there is the inner jihad or struggle against the ego (jihad al-nafs). The prophet referred to the latter as the "greater jihad."

${ }^{19}$ See, for example, John Kelsay and James Turner Johnson, eds., Just War and Jihad: Historical and Theoretical Perspectives on War and Peace in Western and Islamic Traditions (New York: Greenwood Press, 1991); and James Turner Johnson, The Holy War Idea in Western and Islamic Traditions (University Park, PA: The Pennsylvania State University Press, 1997).

${ }^{20} \mathrm{http} / / /$ news.bbc.co.uk/2/hi/2middle east/2751019.stm.

${ }^{21}$ The Washington Post, March 10, 2003.

${ }^{22}$ Sahih Bukhari, Vol. 9, Book 83, No. 49.

${ }^{23}$ Official statement by Abdul Aziz al-Alshaykh, mufti of Saudi Arabia, posted at www.fatwa-online.com/ news/0010917.htm.

${ }^{24}$ See www.islamonline.net/English/News/2001-09/13/article25.shtml.

${ }^{25}$ See Edward William Lane, An Arabic-English Lexicon (8 vols; London: Williams \& Norgate, 1863-1893; repr., Beirut: Librairie du Liban, 1980), pp. 2, 586.

${ }^{26}$ There are, of course, exceptions to this. Radical Islamists often argue that Israeli women, for example, are legitimate targets because they serve in the military.

${ }^{27}$ An English translation of the fatwa was posted at www.azzam.com after September 11. The fatwa was dismissed by reformist Salafis in Saudi Arabia. The Council of Ulama argued that the statement was "not worth adhering to." The council also contested Shuaybi's authority to issue fatwas. See www.fatwaonline.com/news/0011017_1.htm.

${ }^{28}$ Ibn Taymiyya, Majmua al Fatawa, 28/537.

${ }^{29}$ AFP, August 7, 1997.

${ }^{30}$ AFP, January 21, 1997, in FBIS-NES-97-013.

${ }^{31}$ Armed Islamic Group communiqué, issued January 16, 1995.

${ }^{32}$ Al-Majallah, March 14-20, 1999, pp. 21-22, in FBIS-NES-1999-0323.

${ }^{33}$ Armed Islamic Group communiqué, issued April 18, 1996.

${ }^{34}$ See, for example, AFP, September 21, 1994, in FBIS-NES-94-184. 